Oriental Journal of History, Politics and Law

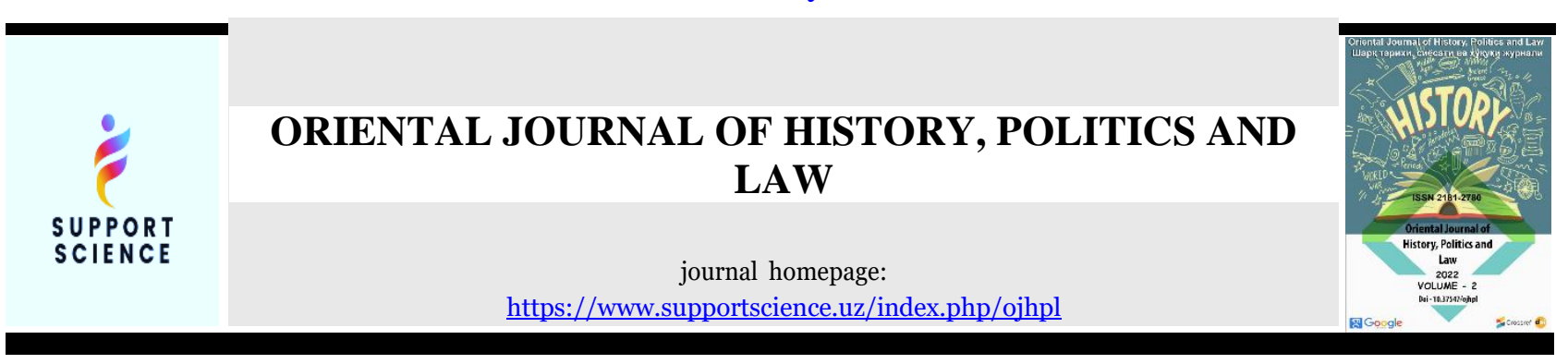

\title{
CHINESE PAINTING AS A SYMBOL OF CHINOISERIE IN MODERN SOCIETY
}

W. Wensziao

Weinan Normal University

1601872206@qq.com

\section{Li Si}

Weinan Normal Universit

1601872206@qq.com

\section{F. Atadjanov}

Siyan Normal University

\section{ABOUT ARTICLE}

Key words: cultural communication, chinese painting, chinoiserie, Mogu painting.

Received: 05.01 .22

Accepted: 12.01 .22

Published: 31.01 .22
Abstract: The article highlights general information about chinoiserie in modern society, describes a series of representative Chinese artificial styles, made a scientific generalization about mogufa.

\section{КИТАЙСКАЯ ЖИВОПИСЬ КАК СИМВОЛ ШИНУАЗЕРИ В СОВРЕМЕННОМ ОБЩЕСТВЕ}

\section{В. Венцзяо}

Вейнанский педагогический университет

1601872206@qq.com

\section{Ли $\boldsymbol{C u}$}

Вейнанский педагогический университет

1601872206@qq.com

\section{Ф. Атаджанов}

Сиянский педагогический университет

\section{О СТАТЬE}

Ключевые слова: культурное общение, Гохуа, шинуазри, могуфа.
Аннотация: В статье освещены общие сведения о шинуазри в современом обществе, описана серия представительных китайских искуственных стилей, выполнено научное обобщение о могуфа.

\section{ВВЕДЕНИЕ}


Время, в которое мы живём - это время культурного общения. Одним из самых больших достижений в XX веке можно считать полное проникновение культурной коммуникации в человеческое общество и человеческую жизнь.

Культурная диффузия стала одной из центральных тем культурологии в XXI веке. Культурная диффузия изменила не только мир, но и людей: сегодня невозможно представить себе жизнь и развитие человека без культурного общения и обмена. Культурная диффузия включает в себя информационное общение и межличностное общение между людьми с разным культурным происхождением, а также распространение, проникновение и миграцию различных человеческих культурных элементов. Человеческая жизнь неотделима от взаимопроникновения культур, которое всегда переплетено со всеми её аспектами, и является обязательной деятельностью между людьми, нациями, странами. Культурная диффузия проникает во многие виды деятельности человеческого общества и способствует социальным изменениям и развитию. Без неё социум не сможет существовать и эволюционировать в полной мере.

Распространение шинуазри в мире является конкретным проявлением культурной диффузии.

\section{МАТЕРИАЛ И МЕТОДЫ}

Шинуазри, называемый также китайским стилем, основан на традиционной китайской культуре и содержит большое количество китайских элементов. Вряд ли шинуазри смог широко распространиться по Европе и в России, если бы не был изящным и не нёс в себе элемент экзотики. Однако шинуазри в начале своего появления репрезентировал китайский стиль в том виде, в котором его понимали европейцы, и имел мало общего с настоящим Китаем. Со временем, в связи с глобализацией и межкультурной коммуникацией, шинуазри стал рассматриваться в качестве культурного феномена Китая, распространился по всему миру.

Шинуазри получает популярность в Европе с конца XVII по конец XVIII в. В России мода на китайский стиль началась со времени правления Петра Великого, к середине XVIII века, то есть во время правления Екатерины II процветала и достигла своего пика развития, оставив потомкам ряд предметов в китайском стиле, таких как Китайский театр, Китайские мостики и Китайский дворец, находящиеся в Царском Селе Санкт-Петербурга. В XIX веке из-за международной тенденции развитие шинуазри замедлилось и стиль практически исчез. Лишь в XX веке по мере того, как китайско-российские отношения становились более тесными, и обмены в области культуры, гуманитарных наук и других аспектов между Китаем и Россией постепенно укрепились, шинуазри как культурное явление снова появилось в России и стало более популярным в начале XXI века. По сей 
день оно все еще находится в периоде бурного развития. Но даже несмотря на увлечение китайским стилем в России, можно говорить о том, что у шинуазри есть большой потенциал для развития.

Из всех китайских культурных элементов Гохуа является самым представительным. Гохуа (GUO HUA国画) - китайская живопись, прямое значение которого является живописью “нашей” страны. Гохуа сильно отличается от западной живописи. Такие различия присутствуют в материалах, технике исполнения и в инструментах. Основная мысль Гохуа символична и иносказательна, нужно тщательно читать и понимать.

\section{РЕЗУЛЬТАТЫ И ИХ ОБСУЖДЕНИЯ}

В традиционной китайской живописи существует два стиля: гунби и се-и. Гунби «техника прилежной кисти», «техника тонкой кисти». В отличие от се-и техника гунби предполагает реалистичность и высокую детализацию предмета, прописывание мелких деталей. Се-и главным образом передаёт идеи и чувств художника. Данный стиль предполагает свободную манеру письма. Главное дух Се-и не заключается в внешнем сходстве, а в своем особом видении, душевном настроении мастера. Невозможно существовать две одинаковой картины се-и, потому что копировать её очень трудно, скорее не возможно.

Обратимся к другом новом стилю Гохуа - могуфа.

Стиль «могуфа» - это метод живописи, представляющий собой нечто среднее между стилем «гунби» и «се-и». Стиль «могуфа» восходит к «Луомохуа» художника Сюй Си эпохи пяти династий (Сначала тушью пишутся ветви и листья, тычинки, чашечки цветов, a затем накладывается цвет). В этом стиле отсутствуют контуры, а объект прорисовывается при помощи цвета. С помощью кисти художник вкладывает в картину тайный смысл. Данный стиль перекликается со стилем «хуанцзя фугуй» (художник Си Шу, создавая картины в жанре «цветы-птицы», использовал яркие цвета, чтобы удовлетворить эстетический вкус высшего общества; так появился роскошный стиль, который впоследствии получил название «хуанцзя фугуй»). Во времена Южной династии Сун появилась монохромная живопись в жанре «цветы-птицы». В эпоху династии Юань и Мин до начального периода правления династии Цинь формируется новая разновидность стиля «се-и» - стиль «шуймо», став новым направлением китайского жанра «цветыптицы». В начале эпохи правления династии Цинь художник Юнь Шоупин усовершенствовал данный стиль, создав жанр «могухуа хуи».

Жанр «цветы-птицы» в стиле «могуфа» отличается от традиционного стиля живописи своим реализмом, простой манерой изложения и оттенками. Стиль «могуфа» является традиционным китайским методом живописи, насчитывающим более тысячи лет. Он 
сменил традиционный метод «гоусиань тяньсе», где тушь применялась для придания цвета, использовались нечеткие линии, чувствовалось стремление к свежести, элегантности, спокойствию, обилие цветов вместо монохромности. В свое время этот жанр стал открытием эпохи. По мере развития живописи происходила интеграция китайской и западной культур. Как показала практика и некоторые произведения живописи, Западный стиль оказал влияние на стиль "могуфа".

Цветовая палитра - это основное средство моделирования в западной живописи, на основе использования контраста теплого и холодного оттенков, контраста светотени, контраста толщины уровней, восприятия света и объема предмета. В китайской живописи средством моделирования выступают линии. Цветовая палитра картины также играет важную роль. Западная концепция цвета и концепция цвета китайской живописи диаметрально противоположны. На цветовую палитру китайской живописи оказала огромное влияние традиционная философия. Она основывается на идеях инь и ян и пяти элементах, а также конфуцианстве, даосизме и таинственной философии дзен. Ей присущи монохромность, чистота, простота и, главное, цвет туши. Западная концепция цвета - научная; она требует, чтобы художник воспроизводил объективный мир, прибегая к совершенно объективному методу.

\section{ЗАКЛЮЧЕНИЯ}

Всем известно, что китайская философия является основой китайской живописи. В китайской живописи находит определённое выражение, глубинную суть духовности и культуру Китая. Основная задача китайской живописи - это философское осмысление бытия человека. В настоящее время могуфа хорошо существует данную функцию.

\section{СПИСОК ЛИТЕРАТУРЫ}

1. Ван Лицзин. Взгляд на особенности сущ-ности китайской живописи «се-и» с точки зрения развития живописного жанра «цветы и птицы»// Журнал Хэбэйского Инженерного Университета (социальныенауки). - 2010. - Т. 27, № 2. - С. 106-107].

2. Завадская Е. В. Слово о живописи из Сада с горчичное зерно. - М.: В. Шевчук, 2001. $-512 \mathrm{c}$.

3. Переломов Л. С. Конфуций: Лунь юй / исслед., пер. с кит., коммент. Л. С. Переломова. Факсимильный текст «Лунь юя» с коммент. Чжу Си. - М.: Издат. фирма «Восточная литература» $\mathrm{PAH,} \mathrm{1998.} \mathrm{-} 588$ с.

4. Чжуан-цзы. Ле-цзы / пер. с кит., вступ.ст. и примеч. В. В. Малявина. - М.:Мысль, 1995. -439 c.

5. Ян Хин-шун. Древнекитайский философ Лао-цзы и его учение / под ред. Л. В. Симоновской, О. И. Саяпиной. - М.-Л.: Издво Академии наук СССР, 1950. - 160 с. 